Antonina Doroszewska

DOI: $10.33896 /$ PorJ.2021.8.4

(Warszawski Uniwersytet Medyczny, Rada Języka Polskiego PAN,

e-mail: antonina.doroszewska@wum.edu.pl)

ORCID: 0000-0003-0764-2105

Iwona Drozdowska

(Warszawski Uniwersytet Medyczny, e-mail: iwona.drozdowska@wum.edu.pl)

ORCID: 0000-0002-0772-6803

\title{
PACJENT W CENTRUM ROZMOWY NA PRZYKEADZIE PRAC STUDENTÓW KIERUNKÓW MEDYCZNYCH
}

\section{WPROWADZENIE}

Pojęcie komunikowanie ma swoje źródło w łacińskim słowie communicare, które oznacza m.in. 'czynić wspólnym, połączyć'. ${ }^{1} \mathrm{~W}$ odniesieniu do relacji lekarz - pacjent stanowi to wskazówkę, co jest podstawowym celem rozmowy i konsultacji medycznej. Codzienne doświadczenia pacjentów wskazują, że często podczas wizyt lekarskich obie strony mówią, ale te wypowiedzi przypominaja monolog. ${ }^{2}$

$\mathrm{W}$ rozmowie personelu medycznego $\mathrm{z}$ pacjentami niezwykle ważne jest to, aby podczas takiego spotkania obie strony miały szansę powiedzieć, $\mathrm{w}$ jaki sposób postrzegaja problem zdrowotny chorego. Jest to istotne zarówno na etapie procesu diagnostycznego, bo dzięki temu profesjonalista medyczny zdobędzie wszystkie informacje niezbędne do ustalenia diagnozy, jak i w procesie leczenia. Pacjent, który zrozumiał informacje o chorobie, będzie świadomy, dlaczego wybrane postępowanie terapeutyczne jest adekwatne do jego stanu zdrowia i jak może zmienić się jego samopoczucie w zależności od starań na rzecz przestrzegania zaleceń lekarskich. Wiele umiejętności komunikacyjnych, które zostaną omówione poniżej, pomaga budować rozmowę służąca „czynieniu wspólnym”. Prowadzona $z$ ich wykorzystaniem rozmowa jest dialogiem, pozwalającym poznać i zrozumieć perspektywę pacjenta, zadać pytania niezbędne do wzajemnego zrozumienia, rozwiać wątpliwości czy niejasności.

Głównym narzędziem tej rozmowy jest język, a także elementy komunikacji niewerbalnej. Jan Doroszewski wyróżnił cztery odmiany języka medycyny:

- język opisu ludzi zdrowych i chorych,

1 K. Kumaniecki, 1996, Słownik łacińsko-polski, Warszawa.

2 J. Silverman, S. Kurtz, J. Draper, 2018, Umiejętności komunikowania się z pacjentami, Kraków, s. 130. 
- język relacji deontycznych łączących personel medyczny z ludźmi zdrowymi i chorymi,

- język porozumienia między ludźmi zdrowymi i chorymi a personelem medycznym,

- $\quad$ język opisujacy leki, aparaturę i medyczne urządzenia pomocnicze. ${ }^{3}$

W każdej z tych odmian można wyróżnić rejestr ogólny i konkretny (szczegółowy). W tej pracy skupimy się na języku porozumienia personelu medycznego z pacjentami. Według J. Doroszewskiego

ogólny język porozumienia lekarzy z pacjentami przedstawia teoretyczne podstawy tej działalności, jest wynikiem badań szczegółowych i doświadczenia praktycznego, jest też przedmiotem nauczania w komunikacji medycznej. Szczegółowy język porozumienia lekarzy $z$ pacjentami jest językiem stosowanym przez nich $w$ związku $z$ diagnoza lekarska, projektem postępowania i podejmowaniem decyzji oraz realizacja pomocy medycznej.

Opisujacc umiejętności komunikacyjne, które sa przedmiotem nauczania studentów medycyny, będziemy odwoływać się do języka ogólnego. Przytoczone wypowiedzi zawarte w pracach studentów stanowią przykład sformułowań zaczerpniętych $z$ języka szczegółowego. ${ }^{4}$

\section{PACJENT W CENTRUM ROZMOWY}

Tradycyjne podejście do wizyty lekarskiej, według którego lekarz odgrywa dominujacca rolę, a pacjent przyjmuje postawę bierna, w ostatnich dziesięcioleciach zostaje zastapione przez model opieki skoncentrowanej na pacjencie, który podkreśla jego indywidualnośc. ${ }^{5} \mathrm{~W}$ tym podejściu zwraca się uwagę nie tylko na biologiczny wymiar choroby, ale także na aspekt psychologiczny i kontekst społeczny. Opieka skoncentrowana na pacjencie skupia się na poznaniu i uwzględnieniu jego perspektywy. Składają się na nią wyobrażenia pacjenta, myśli, przekonania i wiedza dotycząca własnego zdrowia, a także emocje i obawy $z$ nim związane, wcześniejsze doświadczenia własne lub bliskich osób, oczekiwania wobec systemu opieki zdrowotnej oraz to, jak choroba wpływa

3 J. Doroszewski, 2019, Odmiany języka medycyny [w:] M. Kulus, A. Doroszewska, M. Chojnacka-Kuraś (red.), Językowe, prawne i dydaktyczne aspekty porozumiewania się z pacjentem, Warszawa, s. 13-22. Ksiażka dostępna na stronie: https://publikacje.pan.pl/dlibra/journal/136632

4 Nie pochodza $z$ rzeczywistych rozmów, o czym będzie mowa poniżej, mogłyby jednak w takich rozmowach się pojawić.

5 E. Balint, 1969, The possibilities of patient-centered medicine, „J. R. Coll. Gen. Pract." nr 17(82), s. 269-276; https://www.ncbi.nlm.nih.gov/pmc/articles $/$ PMC2236836/?page $=1$ 
na codzienne życie pacjenta. ${ }^{6}$ Poznanie perspektywy jest niezbędne, by planujac postępowanie terapeutyczne, uwzględnić przekonania, obawy, możliwości i oczekiwania chorego, a także, by włączyć go w podejmowanie decyzji o sposobie leczenia, w którym główną rolę odgrywają wartości ważne dla pacjenta. Pomaga to w sposób precyzyjny wybrać rodzaje badań diagnostycznych i wpływa korzystnie na przestrzeganie przez pacjentów zaleceń. ${ }^{7} \mathrm{~W}$ ten sposób odpowiednia komunikacja przekłada się na aspekt finansowy opieki zdrowotnej - wykonywane badania diagnostyczne są lepiej dobrane, wyniki leczenia lepsze ze względu na większy odsetek pacjentów przestrzegajacych zaleceń, a tym samym odnotowuje się mniej wizyt lekarskich. ${ }^{8}$ Poznaniu perspektywy pacjenta podczas wizyty u lekarza sprzyja aktywne słuchanie, w tym m.in. parafrazy, odzwierciedlenia, klaryfikacje, a także pytania otwarte oraz powstrzymanie się od przerywania wypowiedzi pacjenta. ${ }^{9}$ Odpowiednia relacja $z$ pacjentem i komunikacja przyczyniają się do większej satysfakcji $z$ opie$\mathrm{ki},{ }^{10}$ a u lekarzy $-\mathrm{z}$ pracy, a przeciwdziałaja frustracji, ${ }^{11}$ zmniejszaja liczbę skarg pacjentów, ${ }^{12}$ sprzyjaja również bardziej efektywnemu wykorzystaniu czasu podczas wizyty. ${ }^{13}$ Podsumowujac, kompetencje komunikacyjne pozwalaja $z$ jednej strony uwzględniać potrzeby chorych, $z$ drugiej chronia personel medyczny przed frustracja i skargami. Ma to więc wpływ na wynik leczenia i, szerzej, aspekt finansowy systemu ochrony zdrowia.

6 J. Silverman, S. Kurtz, J. Draper, 2018, Umiejętności komunikowania sie z pacjentami, Kraków, s. 127-137.

7 S. Górski, 2018, Komunikacja w wywiadzie lekarskim [w:] M. Nowina Konopka, W. Feleszko, Ł. Małecki (red.), Komunikacja medyczna dla studentów i lekarzy, Kraków, s. 80.

8 S. Trzeciak, A. Mazzarelli, 2019, Compassionomics: The Revolutionary Scientific Evidence that Caring Makes a Difference, Pensacola.

9 S. Górski, 2018, Komunikacja w wywiadzie lekarskim [w:] M. Nowina Konopka, W. Feleszko, Ł. Małecki (red.), Komunikacja medyczna dla studentów i lekarzy, Kraków, s. 78-80.

10 A. Boissy, A.K. Windover, D. Bokar, M. Karafa, K. Neuendorf, R.M. Frankel, J. Merlino, M.B. Rothberg, 2016, Communication Skills Training for Physicians Improves Patient Satisfaction, „J. Gen. Intern. Med.” nr 31(7), s. 755-761.

11 J. Silverman, S. Kurtz, J. Draper, 2018, Umiejętności komunikowania się $z$ pacjentami, Kraków, s. 48.

12 T.E. Adamson, W.H. Bunch, D.C. Baldwin, A. Oppenberg, 2000, The wirtuos orthopaedist has fewer malpractice suits, "Clinical Orthopaedics and Related Research" nr 378, s. 104-109.

13 S. Trzeciak, A. Mazzarelli, 2019, Compassionomics: The Revolutionary Scientific Evidence that Caring Makes a Difference, Pensacola. 


\section{PACJENT W CENTRUM ROZMOWY - KSZTALCENIE KOMPETENCJI KOMUNIKACYJNYCH NA WARSZAWSKIM UNIWERSYTECIE MEDYCZNYM}

Zmiany społeczne, w tym przede wszystkim zmieniające się postawy pacjentów, którzy chca być traktowani jako partnerzy interakcji, rozpowszechnienie modelu opieki skoncentrowanej na pacjencie, lepszy dostęp do wiedzy medycznej nie tylko dla profesjonalistów, ale dla każdej osoby zainteresowanej tym tematem, wyniki badań potwierdzające wpływ komunikacji na efektywność postępowania terapeutycznego sprawiły, że w programach kształcenia na kierunkach medycznych pojawiły się zajęcia rozwijające umiejętność budowania relacji i prowadzenia rozmowy. Od kilku lat także polskie uczelnie medyczne wprowadzaja obowiazkowe zajęcia $z$ komunikacji. Można wyróżnić dwa główne cele tego kształcenia, a mianowicie rozwijanie empatycznej postawy wobec chorych, a także rozwijanie konkretnych umiejętności komunikacyjnych.

Główne koncepcje programu nauczania w zakresie komunikacji zakładaja, że podstawa umiejętności jest wiedza, a także, że w pierwszej kolejności należy rozwijać umiejętności proste, związane $z$ mniejszym ładunkiem emocjonalnym, a następnie bardziej złożone, uwzględniając przy tym różne sytuacje, które wywołują silne emocje, takie jak frustracja czy złość pacjenta lub konieczność przekazania przez lekarza niepomyślnej informacji. Proces kształcenia $z$ komunikacji powinien być także rozłożony w czasie; rozpoczynać się na początku studiów medycznych i trwać aż do ostatniego roku. Zalecenia te zostały przedstawione m.in. w Rekomendacjach Polskiego Towarzystwa Komunikacji Medycznej dotyczacych ksztakcenia kompetencji komunikacyjnych na kierunkach lekarskim i lekarsko-dentystycznym. ${ }^{14}$

Powyżej opisane założenia stoją u podstaw programu nauczania w zakresie komunikacji, który od 2018 roku jest realizowany na Warszawskim Uniwersytecie Medycznym. Pierwsze zajęcia $z$ komunikacji studenci na kierunku lekarskim maja na II roku, potem na III i na VI roku. Na IV i V roku umiejętności komunikacyjne są rozwijane podczas zajęć klinicznych. Na VI roku zajęcia $z$ komunikacji odbywaja się w Centrum Symulacji Medycznych. Podczas tych zajęć studenci ćwiczą równocześnie wykonywanie określonych czynności medycznych $z$ koniecznością radzenia sobie w sytuacjach trudnych $z$ punktu widzenia interpersonalnego.

14 M. Borowczyk, M. Chojnacka-Kuraś, A. Doroszewska, A.K. Jankowska, Z. Kowalski, M. Libura, M. Małecki, A. Stalmach-Przygoda, Rekomendacje Polskiego Towarzystwa Komunikacji Medycznej dotyczace kształcenia kompetencji komunikacyjnych na kierunkach lekarskim i lekarsko-dentystycznym, Bydgoszcz, Kraków, Olsztyn, Poznań, Warszawa, marzec 2021, dokument dostępny na stronie: https://komunikacjamedyczna.pl/wp-content/uploads/2021/03/ConsensusPTKM2.pdf [dostęp 12 lipca 2021 r.]. 
Celem artykułu jest ukazanie, w jaki sposób umiejętności komunikacyjne, które sa przedmiotem nauczania w ramach zajęć $z$ komunikacji medycznej, pomagają sprawować opiekę nad pacjentem. Poniżej opisałyśmy wybrane umiejętności komunikacyjne, które są rozwijane w trakcie kształcenia $z$ komunikacji medycznej i zaprezentowałyśmy, w jaki sposób spożytkowuja je studenci w prowadzonych przez siebie rozmowach.

Przed ćwiczeniami majacymi kształtować umiejętności studenci mają wykłady, których celem jest zapoznanie $z$ podstawami teoretycznymi związanymi $z$ budowaniem relacji i komunikacja $z$ pacjentami, a także komunikacja w zespole terapeutycznym. Założenia metodyczne oraz organizacja tych zajęć została opisana w ksiażce Językowe, prawne $i$ dydaktyczne aspekty porozumiewania sie $z$ pacjentem pod redakcja M. Kulusa, A. Doroszewskiej i M. Chojnackiej-Kuraś. ${ }^{15}$

W celu zaliczenia wykładów, przed pierwszymi zajęciami praktycznymi, na których studenci ćwiczą najpierw umiejętności komunikacyjne $\mathrm{w}$ ramach dyskusji i pracy w małych grupach, potem podczas rozmów $z$ symulowanymi pacjentami, studenci musza napisać fragment rozmowy $z$ pacjentem. Przygotowana rozmowa ma dotyczyć jednego wybranego tematu: motywowania pacjenta lub poradzenia sobie $z$ jego oczekiwaniami, które są trudne do zaspokojenia. Zgodnie $z$ poleceniem praca ma mieć nie mniej niż 100 i nie więcej niż 300 słów. W celu utrwalenia wybranych umiejętności komunikacyjnych sa one wskazane w formularzu zadania jako te, które muszą być wykorzystane w rozmowie. W zależności od wybranego tematu rozmowy wymagane jest spożytkowanie elementów związanych $z$ podanymi wcześniej umiejętnościami komunikacyjnymi. Przygotowując pracę majacca na celu motywowanie pacjenta, studenci muszą użyć umiejętności takich jak: pytanie otwarte, stwierdzenie odzwierciedlające, dowartościowanie, podsumowanie. Punktem odniesienia sa umiejętności opisane przez Williama R. Millera i Stephena Rollnicka w książce poświęconej dialogowi motywującemu. ${ }^{16}$ Pisząc rozmowę, w której zadaniem lekarza jest poradzenie sobie $z$ oczekiwaniami pacjenta, studenci mają dowiedzieć się więcej o problemie chorego, okazać zrozumienie, zapewnić o chęci pomocy oraz przedstawić tok myślenia specjalisty. Te elementy służą utrwaleniu schematu postępowania w takich sytuacjach opisanego przez $\mathrm{E}$. Małeckiego. ${ }^{17}$

Źródłem przykładów podanych w artykule sa prace 578 studentów II roku kierunku lekarskiego, przygotowane w roku akademickim

15 M. Kulus, A. Doroszewska, M. Chojnacka-Kuraś (red.), 2019, Językowe, prawne $i$ dydaktyczne aspekty porozumiewania się z pacjentem, Warszawa. Ksiażka dostępna na stronie: https://publikacje.pan.pl/dlibra/journal/136632

16 W.R. Miller, S. Rollnick, 2014, Dialog motywujacy. Jak pomóc ludziom $w$ zmianie, Kraków.

17 Ł. Małecki, 2018, Radzenie sobie z oczekiwaniami pacjenta [w:] M. Nowina Konopka, W. Feleszko, Ł. Małecki (red.), Komunikacja medyczna dla studentów i lekarzy, Kraków, s. 123-140. 
2020/2021. Sa to zatem opracowania napisane przez studentów dopiero zaczynających przygodę $z$ nauką komunikacji medycznej. Napisanie rozmowy ma być pierwszym ćwiczeniem, w którym studenci mają za zadanie ubrać w konkretne słowa i zdania treści wypowiadane do pacjenta, a także wykorzystać umiejętności, o których była mowa podczas wykładów, do odpowiedniej reakcji na zachowanie pacjenta. Taka forma ma oczywiście ograniczenia, nie sprawdza komunikacji w bezpośrednim kontakcie $z$ pacjentem, przedstawia sytuację wyobrażona, wobec tego nie wiemy, jak w rzeczywistości zareagowałby pacjent i co by odpowiedział. W pracy pisemnej nie widzimy także mowy niewerbalnej, jeżeli student jej nie opisał i nie wiemy, $z$ jaka intonacja głosu wypowiedziane byłyby opisane zdania. Przygotowanie pracy, w której student ma rozpisać dialog między specjalista a pacjentem, stanowi punkt wyjścia późniejszych rozmów, które odbywają się podczas ćwiczeń i sprawdza się jako pierwsze ćwiczenie mobilizujące do stworzenia konkretnych wypowiedzi.

Prezentowane poniżej fragmenty prac zawieraja wybrane sformułowania obrazujące, jak można, wykorzystując określone umiejętności komunikacyjne, prowadzić rozmowę w taki sposób, by komunikacja służyła wymianie perspektyw i budowaniu wspólnego spojrzenia na problem chorego, a także by wzmacniała u pacjenta poczucie, że jest w centrum opieki. W przytoczonych fragmentach prac została zachowana oryginalna pisownia.

\section{PACJENT W CENTRUM ROZMOWY - KOMUNIKACJA NIEWERBALNA}

Nawiązanie kontaktu $z$ pacjentem odbywa się w sposób niewerbalny i werbalny. Do niewerbalnych form zainicjowania wizyty zalicza się kontakt wzrokowy, gest zapraszajacy pacjenta do gabinetu, wstanie $z$ krzesła, podanie ręki. Do werbalnych form kontaktu należy przywitanie się $z$ pacjentem, słowa zaproszenia do gabinetu, przedstawienie się. ${ }^{18}$

Omawiane prace studentów sa zadaniami pisemnymi, dlatego nie jest możliwe przeanalizowanie, jak student zaplanowałby pierwsze chwile w gabinecie lekarskim, zwłaszcza elementy dotyczace komunikacji niewerbalnej. Wielu studentów uwzględniło jednak również ten aspekt w swoich zadaniach, dając dodatkowy opis do sytuacji, w której odbywa się przygotowana rozmowa:

Specjalista przygotował odpowiednie pomieszczenie do rozmowy z pacjentką oraz wyłączył telefon.

Rozmowa ma miejsce w pustym gabinecie lekarskim.

18 A. Kocurek, B. Kowalska, 2018, Inicjowanie konsultacji [w:] M. Nowina Konopka, W. Feleszko, Ł. Małecki (red.), Komunikacja medyczna dla studentów i lekarzy, Kraków, s. 49-55. 
Studenci podkreślali także, że relacja zaczyna się w chwili zaproszenia pacjenta do gabinetu:

Przejdźmy proszę do gabinetu, żeby spokojnie porozmawiać. Proszę usiąść.

Dzień dobry, zapraszam do gabinetu. Proszę tutaj usiąść (lekarka pokazuje dłonia na krzesło, na którym może usiąść pacjentka).

W jednej $z$ prac student przy każdej wypowiedzi wskazywał na elementy komunikacji niewerbalnej:

Dzień dobry, Pani X! (podaje rękę) Zapraszam, proszę usiąść (gestem wskazuje miejsce przed soba).

W wielu pracach studenci rozpoczynali rozmowę od przedstawienia się:

Dzień dobry, nazywam się dr Kowalska, jestem neurologiem.

Warto także zwrócić uwagę, że studenci wskazywali na niewerbalne sposoby okazywania pozytywnej postawy wobec pacjenta:

Dzień dobry (lekarka się uśmiecha). Co Panią sprowadza do mnie? Proszę opowiedzieć.

Uwzględnienie opisanych powyżej elementów, mimo że nie były one jasno wskazane w wytycznych do przygotowania pracy, świadczy o tym, że duża część studentów ma świadomość, jak ważne są odpowiednie otoczenie, atmosfera rozmowy, a także elementy komunikacji niewerbalnej.

\section{PACJENT W CENTRUM ROZMOWY - KOMUNIKACJA WERBALNA. AKTYWNE SEUCHANIE}

Do podstawowych umiejętności komunikacyjnych, które pokazuja, że uwaga lekarza jest skupiona na pacjencie, należy aktywne słuchanie. Badania pokazuja, że w trakcie zbierania wywiadu lekarze przerywaja wypowiedzi pacjenta średnio po $18-23$ sekundach. ${ }^{19}$ Zbyt mała liczba informacji może w większym stopniu utrudnić ustalenie diagnozy niż ich nadmiar. Aktywnym słuchaniem lekarz okazuje pacjentowi, że słucha, sprawdza, czy dobrze zrozumiał wszystkie informacje przekazane przez chorego, weryfikuje, co dla pacjenta jest szczególnie istotne. Może być

19 H.B. Beckman, R.M. Frankel, 1984, The effect of physician behavior on the collection of data, „Ann. Intern. Med.” nr 101(5), s. 692-696; M.K. Marvel, R.M. Epstein, K. Flowers, H.B. Beckman, 1999, Soliciting the patient's agenda: have we improved?, „JAMA” nr 281(3), s. 283-287. 
ono wyrażone w formie niewerbalnej i werbalnej. Niewerbalne okazywanie pacjentowi, że jest słuchany przejawia się jako chwila ciszy zachęcająca go do dalszego mówienia, utrzymywanie kontaktu wzrokowego, otwarta postawa ciała, a także gesty potakiwania. ${ }^{20}$

Niewerbalne przejawy aktywnego słuchania zostały wyrażone w pracach studentów w następujący sposób:

Lekarz uśmiechnął się i lekko skinął głową.

Nic nie mówi, kiwa głową.

Do werbalnych form aktywnego słuchania należa partykuły $u h m$, $a h a$, a także stosowanie parafraz, odzwierciedleń, o których mowa poniżej.

\section{PARAFRAZY}

Parafrazy to krótkie podsumowania tego, co pacjent powiedział. Ważne, by nie były dosłownym powtórzeniem, lecz by lekarz wypowiadał je własnymi słowami. Dzięki parafrazom chory przekonuje się, że lekarz go słuchał, zrozumiał, ma możliwość dodania istotnej informacji lub poprawienia czegoś, co zostało zrozumiane niezgodnie $z$ intencja. Studenci często wykorzystywali parafrazy w swoich pracach, formułujac je w następujacy sposób:

Widzę, że ma Pani duże wsparcie ze strony męża.

Pewnie zastanawia się Pan jak teraz będzie wyglądało pana życie.

Widzę, że bardzo się Pani stara i zależy Pani na zadbaniu o swoje zdrowie. Jednocześnie ma Pani problem $z$ radzeniem sobie ze stresem.

Słyszę, że boi się pan tego, że nie będzie pan w stanie kontynuować pracy, przez co pana sytuacja materialna będzie zła.

Rozumiem, że dla Pana jest to duża zmiana i nie wie Pan od czego zaczać.

Rozumiem, że podejmowała Pani wielokrotne próby stosowania się do zaleceń żywieniowych o których Pani ostatnio mówiłem. Ponadto martwi się Pani o to, że Pani zdrowie może ucierpieć, ze względu na życie rodzinne.

Stara się Pani przestrzegać diety, ale ciężko jest Pani stosować się do zaleceń ze względu na brak czasu.

$Z$ tego co Pani mówi, wynika, że doświadcza Pani paru różnych problemów. Martwi się Pani o wytrwałość w powrocie do zdrowia (...). Martwi się Pani również, że Pani powrót do zdrowia może również sprawić problemy swojej rodzinie.

Parafrazy studenci budują w taki sposób, że odwołują się do tego, co usłyszeli w wypowiedzi pacjenta (widzę, słyszę, że...) lub używając stwierdzeń, podsumowują to, co chory powiedział. Należy jednak pod-

20 S. Górski, 2018, Komunikacja w wywiadzie lekarskim [w:] M. Nowina Konopka, W. Feleszko, Ł. Małecki (red.), Komunikacja medyczna dla studentów i lekarzy, Kraków, s. 70-71. 
kreślić, że nie ma tu dosłownych powtórzeń słów pacjenta, powtarzana jest treść wypowiedzi. Istotne jest także to, że parafraza odnosi się do sytuacji, o której mówił pacjent, nie zawiera informacji dodawanych przez lekarza.

Często pomocne jest zastosowanie parafrazy $z$ upewnieniem się, czy lekarz dobrze zrozumiał perspektywę pacjenta. Takie połaczenie parafrazy $z$ pytaniem pokazuje poniższy fragment pracy:

Rozumiem, że nowa sytuacja spowodowała, że ma Pan teraz bardzo ciężką drogę do pokonania. Wydaje się ona na tyle trudna, że nie potrafi pan sobie jeszcze tego teraz wyobrazić, ponieważ wszystkie te trudności sa dla Pana zupełnie nowe. Czy mniej więcej dobrze zrozumiałam Pana obecna sytuację?

\section{ODZWIERCIEDLENIA}

Budowaniu relacji, okazaniu zrozumienia i empatii służą także odzwierciedlenia. Sa to wypowiedzi, w których lekarz nazywa emocje, o których mówił pacjent, krótko podsumowuje spostrzeżenia czy opinie chorego. W toku kształcenia umiejętności komunikacyjnych zwracamy na to uwagę, wskazując, że często są one bardziej trafne niż krótkie powiedzenie: aha, rozumiem pana bez odniesienia się do tego, co zostało powiedziane. W pracach studentów można znaleźć następujące przykłady odzwierciedleń:

Widzę, że jest Pan zaniepokojony.

To musi być niezwykle nużące.

Widzę, że odczuwa pan niechęć do tego pomysłu.

Wszystko wydaje się Panu dość przytłaczające.

Jest Pani zaangażowana w tę zmianę.

Widzę, że czuje się Pani sfrustrowana.

Przeraża panią to, że nie potrafi pani zapanować nad chęcią zjedzenia słodyczy.

Podobnie jak w parafrazie, formułując odzwierciedlenie, lekarz odnosi się do tego, co mówił pacjent. W odzwierciedleniu, jak widać to w powyższych przykładach, znajduje się nazwanie czyjejś emocji, obawy, myśli czy postawy. Pojawia się zatem podsumowanie, interpretacja, wniosek. Odzwierciedlenie, nazywające np. emocję, stanowi swego rodzaju odbicie, niczym w lustrze, sytuacji, o której mówi chory. Może to sprawić, że pacjent spojrzy na swoją sytuację $z$ innej perspektywy, usłyszy, zauważy pewne rzeczy, których wcześniej nie widział. Słyszac odzwierciedlenie, chory może też upewnić się, że lekarz go słuchał i zrozumiał. 


\section{DOWARTOŚCIOWANIA}

Dowartościowanie to sformułowanie, w którym lekarz docenia starania pacjenta, by dbać o swoje zdrowie. To staranie może się przejawiać $\mathrm{w}$ tym, że chory zaczął myśleć o zmianie w stylu życia, która jest korzystna $z$ punktu widzenia zdrowia, $w$ tym, że pacjent zaczą poszukiwać informacji, jak może poprawić swoje samopoczucie, ale też w tym, że mimo trudności wynikających np. $z$ sytuacji zawodowej przestrzega zaleceń lekarskich. Znaczenie dowartościowań w komunikacji oraz motywowaniu pacjentów do przestrzegania zaleceń, podejmowania wysiłku na rzecz zmiany sprzyjajacej zdrowiu podkreślają m.in. W.R. Miller i S. Rollnick. ${ }^{21}$ Wplecenie do rozmowy dowartościowania jest jednym $z$ zadań studentów, którzy piszą rozmowę mającą na celu motywowanie pacjenta.

Widzę, że pomimo pandemii jest Pan jak zawsze ambitny i sumienny.

Widzę, że jest w Pani dużo motywacji by jednak zmienić swoje nawyki.

Widzę, że się Pani bardzo stara i jest zdeterminowana, aby zredukować masę ciała skoro udało się wprowadzić zmiany w jadłospisie i stosować zalecona aktywność.

Bardzo prosiłabym Panią o wytrwałość. Na razie świetnie Pani idzie i jeżeli uda się pozostać przy zaproponowanych przeze mnie rozwiązaniach uda się skutecznie zmniejszyć masę ciała, a wtedy pomyślimy, aby wprowadzić inne rodzaje aktywności fizycznej, które będą Pani sprawiać radość.

To imponujace, że tak pan do tego podchodzi. Rzucenie palenia to naprawdę dobra decyzja, a pozytywne myśli na pewno będą sprzyjały leczeniu.

Dyskutując ze studentami o dowartościowaniach, podkreślamy, że musza być autentyczne, czyli muszą odnosić się do rzeczywistych starań, które podją pacjent. Jeśli zdarzy się, że sa „na wyrost”, np. na pewno będzie Pani świetna matka wypowiedziane w pierwszych minutach kontaktu $z$ położnica, przypominają technikę manipulacyjną i wielu pacjentów może wyczuć fałsz lub nieszczerość takiej wypowiedzi. Należy podkreślić, że przytoczone przykłady dowartościowań $z$ prac studentów odnosiły się do treści wypowiadanych wcześniej przez pacjenta.

\section{PYTANIA OTWARTE}

Dobra rozmowa $z$ pacjentem to przede wszystkim stworzenie odpowiednich warunków do opowiedzenia przez chorego o sytuacji, w której się znajduje i zwiazanych $z$ nią emocjach, a także oczekiwaniach. Od rodzaju zadawanych pytań zależy, jakie informacje lekarz uzyska. Pytania otwarte i zamknięte sa bardzo istotne podczas wizyty i umożliwiaja wydobycie różnych informacji. Pytania zamknięte służą do uzyskania kon-

21 W.R. Miller, S. Rollnick, 2014, Dialog motywujacy. Jak pomóc ludziom $w$ zmianie, Kraków. 
kretnej odpowiedzi, zwykle zawartej w jednym słowie lub dwóch. Sa więc bardzo pomocne przy poszukiwaniu szczegółowych, konkretnych informacji, np. czy chory jest na czczo, czy bierze jakieś leki, czy miał operacje. Na początku wizyty, przy poznawaniu punktu widzenia i odczuć (perspektywy) pacjenta, gdy lekarz chce się zorientować, $z$ jakimi problemami zgłasza się pacjent, istotną rolę odgrywają pytania otwarte. Dzięki pytaniom tego rodzaju pacjent ma szansę opowiedzieć historię swojej choroby w szerszej perspektywie, uwzględniającej jego życie zawodowe czy rodzinne. Pozwala to lekarzowi uzyskać większą liczbę informacji obrazujących problem medyczny pacjenta w kontekście całego życia chorego. Przekłada się to na większą efektywność procesu diagnostycznego. Dłuższe odpowiedzi na pytania otwarte umożliwiają także lekarzowi wychwycenie ważnych sygnałów, które moga pojawić się podczas wypowiedzi pacjenta, zarówno werbalnych, jak i niewerbalnych. Dzięki pytaniom otwartym lekarz może ponadto poznać słownictwo, jakim posługuje się pacjent, co pomaga mu na dalszym etapie wizyty dobrać język dostosowany i zrozumiały dla pacjenta. Pytania otwarte angażuja pacjenta w przebieg wizyty, nadaja spotkaniu charakter wizyty skoncentrowanej na chorym, podczas której ważne jest, aby pacjent nie pozostawał bierny. Sygnalizuja pacjentowi, że jego aktywna postawa jest pożądana, a informacje, które wnosi do wywiadu są ważne i dobrze, że o nich mówi. ${ }^{22}$

W analizowanych pracach studentów pytania otwarte odgrywały ważna rolę. Pojawiały się one zarówno na początku wizyty:

Dzień dobry, w czym mógłbym panu pomóc?,

Proszę mi powiedzieć, dlaczego przyszedł Pan dzisiaj do mnie?,

jak i na jej dalszych etapach:

Mogłaby pani opowiedzieć mi więcej o diecie, którą stosuje oraz o ewentualnych suplementacjach?

Pytania otwarte moga być pomocne $\mathrm{w}$ angażowaniu pacjenta w proces leczenia i służyć do wzbudzenia jego motywacji, gdy za ich pomoca profesjonalista będzie chciał wydobyć od pacjenta jego pomysły na rozwiązanie trudności $z$ wdrożeniem zaleceń w życie, zamiast przedstawiać swoje propozycje w formie wykładu. Studenci mieli świadomość, jak bardzo jest to pomocne i stosowali pytania otwarte w tym celu w swoich pracach. Pojawiały się takie wypowiedzi:

Widzę, że sprawia to Pani dużo bólu. Jak Pani myśli co mogłoby Pani pomóc w tej sytuacji?

22 J. Silverman, S. Kurtz, J. Draper, 2018, Umiejętności komunikowania się z pacjentami, Kraków, s. 140-148. 
Czy myślała Pani nad jakimiś rozwiązaniami, które ułatwiłyby pogodzenie pracy ze stosowaniem się do diety?

Pojawiały się także sformułowania zachęcajace pacjenta do współpracy oraz pokazujace $\mathrm{mu}$, że nie jest sam w procesie leczenia, że specjalista będzie mu towarzyszył na wszystkich etapach „działań na rzecz zdrowia":

Może przejdziemy przez wszystkie moje rady jeszcze raz i zobaczymy jak możemy małymi kroki wprowadzić odpowiednie nawyki w Pani życie?

\section{PACJENT W CENTRUM ROZMOWY DZIĘKI ODPOWIEDNIEMU JĘZYKOWI}

W komunikacji z pacjentem bardzo ważne jest, aby lekarz dbał o odpowiedni język rozmów. Posługiwanie się przez lekarza językiem medycznym sprawia, że pacjent nie rozumie, o czym jest mowa. Nawet chorzy mający wykształcenie medyczne często podkreślaja, że wiedza medyczna podczas choroby nie pomaga zrozumieć własnej sytuacji, że potrzebują wyjaśnień i wsparcia tak samo jak każdy chory. W ten sposób ujęła to jedna $z$ lekarek chorujacych na nowotwór badanych przez T. Chmielewską-Ignatowicz:

Nie chcę nikogo obwiniać ani usprawiedliwiać, ale ktoś, kto mówi taką diagnozę musi zrozumieć sytuację pacjenta... nie ważne, że pacjent jest lekarzem... w tej chwili jest pacjentem, który chce wiedzieć, co robić dalej... . ${ }^{23}$

Należy pamiętać, że chory nie zawsze dopyta, by zrozumieć, o czym mowa, ze względu na obawy, czy nie zostanie uznany za osobę niekompetentną. Dlatego tak ważne jest, aby język profesjonalisty był dostosowany do pacjenta. $W$ rozmowie $z$ chorym lekarz powinien zatem posługiwać się językiem potocznym, naturalnym, który jest zrozumiały dla danego chorego. Dażąc do zrozumienia sytuacji, w której znajduje się pacjent, jest cenne, by lekarz poznał, w jaki sposób pacjent opisuje swój świat. W tym miejscu warto nawiązać do prac J. Bartmińskiego, który pisał o perspektywie, definiując ja jako całościowy efekt ujmowania przedmiotu pod różnymi, uzupełniającymi się względami. Ten termin pojawia się w tym tekście wielokrotnie, w komunikacji medycznej odpowiada mu określenie perspektywa pacjenta. Rozmawiajac $z$ pacjentem, warto, by lekarz usłyszał, jaki jest jego punkt widzenia, jak chory opisuje swój świat, w którym doświadcza określonych problemów medycznych. Zwracając się do pacjenta, lekarz może odwoływać się do tego sposobu postrzegania

23 T. Chmielewska-Ignatowicz, 2018, Lekarz jako pacjent onkologiczny. Analiza narracji [w:] Współczesne problemy w naukach o zdrowiu, Warszawa, s. $27-40$. 
świata, wykorzystywać słownictwo, którym posługuje się pacjent. Może to wyrazić na przykład w taki sposób:

A więc myśli Pani o swojej chorobie jako o cieniu, który zawsze będzie Pani towarzyszył.

Dzięki temu pacjent będzie czuł, że rozmowa, a za tym pomoc, której udziela lekarz, jest dostosowana do tej konkretnej sytuacji i potrzeb chorego. W literaturze $z$ zakresu komunikacji medycznej określane jest to jako nawiazywanie do perspektywy pacjenta i szczególnie zalecane na etapie uzgadniania planu postępowania terapeutycznego. A. Stalmach-Przygoda podkreśla, że:

takie nawiąanie umożliwia prawdziwy dialog w trakcie konsultacji medycznej. Pokazuje to pacjentowi, że przedstawione przez niego treści zostały wysłuchane i potraktowane ze zrozumieniem. Zarazem też jest ważnym elementem zaangażowania pacjenta w leczenie, ponieważ skłania go do uczestniczenia - w ramach jego roli i kompetencji - w procesie podejmowania decyzji dotyczących sposobu postępowania. ${ }^{24}$

Powyżej jest mowa o pewnym założeniu stosowania języka zrozumiałego dla pacjenta, w praktyce może się jednak okazać, że mimo starań pewne kwestie pozostaja dla chorego niejasne. Aby temu zapobiec, w procesie nauczania rozwijana jest także umiejętność „tnij i sprawdzaj”, a zatem zalecenie, by lekarz dzielił informacje na mniejsze części i sprawdzał, czy pacjent je właściwie zrozumiał. ${ }^{25}$ Studenci byli świadomi ważności tego aspektu, co znalazło odzwierciedlenie w ich pracach:

Pacjent: Ale Pani Doktor, nie rozumiem, dlaczego ten cholesterol wzrósł? Lekarz: Proszę sobie wyobrazić, że cholesterol jest drobinkami tłuszczu pływającymi we krwi. Źródłem tego tłuszczu sa spożywane pokarmy. To znaczy, że im tłustsze pokarmy Pan spożywa, tym szybciej poziom cholesterolu będzie się podnosił. (...) Proszę powiedzieć, czy na ten moment wszystko jest jasne?

W opisanym przykładzie lekarz, używając potocznego języka, tłumaczy wyniki badań, upewniając się na koniec, czy na pewno wszystko jest dla pacjenta jasne. W innej pracy student zwrócił uwagę na to, aby przekazując skomplikowaną informację, zapewnić pacjenta, że zaraz zostanie mu ona dokładnie wyjaśniona: „Zaraz to rozpiszę i wytłumaczę”. W ten sposób uprzedza pytania i uspokaja pacjenta.

\section{ZAKOŃCZENIE}

24 A. Stalmach-Przygoda, 2018, Wyjaśnianie i planowanie [w:] M. Nowina Konopka, W. Feleszko, Ł. Małecki (red.), Komunikacja medyczna dla studentów i lekarzy, Kraków, s. 99-114.

25 Ibidem. 
W artykule zaprezentowałyśmy główne umiejętności komunikacyjne, które sprzyjaja kształtowaniu sytuacji wizyty skoncentrowanej na pacjencie, przedstawiłyśmy również, w jaki sposób studenci pierwszych lat wykorzystuja je w swoich pierwszych, wyobrażonych rozmowach $z$ chorymi. Szczegółowa analiza treści rozmów wykracza poza ramy artykułu. Dzięki tym umiejętnościom i zwracaniu uwagi na język, którego lekarz używa podczas wizyty, pacjent jest otoczony właściwa opieka, dostosowana do jego indywidualnej sytuacji. Rozmowa staje się dialogiem, w którym obie strony przyjmuja aktywna i uważna postawę. Pozwala to lekarzowi poznać świat pacjenta, zrozumieć, jakiej pomocy chory potrzebuje, co wpływa na satysfakcję obu stron, a także zapewnia bezpieczeństwo pacjenta, ma to bowiem wpływ na dobór właściwego postępowania terapeutycznego. Jak powiedział George Bernard Shaw: „największym problemem w komunikacji jest iluzja, że do niej doszło".

\section{Bibliografia}

E. Balint, 1969, The possibilities of patient-centered medicine, „The Journal of the Royal College of General Practitioners" nr 17(82), s. 269-276; https:// www.ncbi.nlm.nih.gov/pmc/articles/PMC2236836/?page $=1$

J. Bartmiński, 1990, Punkt widzenia, perspektywa, jezzykowy obraz świata [w:] J. Bartmiński (red.), Językowy obraz świata, Lublin, s. 109-127.

H.B. Beckman, R.M. Frankel, 1984, The effect of physician behavior on the collection of data, „Annales of Internal Medicine” nr 101(5), s. 692-696.

A. Boissy, A.K. Windover, D. Bokar, M. Karafa, K. Neuendorf, R.M. Frankel, J. Merlino, M.B. Rothberg, 2016, Communication Skills Training for Physicians Improves Patient Satisfaction, „J. Gen. Intern. Med.” nr 31(7), s. 755-761; https://www.ncbi.nlm.nih.gov/pmc/articles/PMC4907940/

M. Borowczyk, M. Chojnacka-Kuraś, A. Doroszewska, A.K. Jankowska, Z. Kowalski, M. Libura, M. Małecki, A. Stalmach-Przygoda, Rekomendacje Polskiego Towarzystwa Komunikacji Medycznej dotyczace kształcenia kompetencji komunikacyjnych na kierunkach lekarskim i lekarsko-dentystycznym, Bydgoszcz, Kraków, Olsztyn, Poznan, Warszawa, marzec 2021; https://komunikacjamedyczna.pl/wp-content/uploads/2021/03/ConsensusPTKM2.pdf [dostęp 12 lipca 2021 r.].

T. Chmielewska-Ignatowicz, 2018, Lekarz jako pacjent onkologiczny. Analiza narracji [w:] Wspótczesne problemy w naukach o zdrowiu, Warszawa, s. 27-40.

B. Chwieralska, M. Witt, 2018, Podstawy komunikacji z pacjentem [w:] M. Nowina Konopka, W. Feleszko, Ł. Małecki (red.), Komunikacja medyczna dla studentów i lekarzy, Kraków, s. 11.

J. Doroszewski, 2019, Odmiany jezyka medycyny [w:] M. Kulus, A. Doroszewska, M. Chojnacka-Kuraś (red.), Językowe, prawne $i$ dydaktyczne aspekty porozumiewania sie z pacjentem, Warszawa, s. 13-22; https://publikacje. pan.pl/dlibra/journal/136632 
S. Górski, 2018, Komunikacja w wywiadzie lekarskim [w:] M. Nowina Konopka, W. Feleszko, Ł. Małecki (red.), Komunikacja medyczna dla studentów i lekarzy, Kraków, s. 70-80.

M. Kulus, A. Doroszewska, M. Chojnacka-Kuraś (red.), 2019, Językowe, prawne i dydaktyczne aspekty porozumiewania sie z pacjentem, Warszawa; https:/ / publikacje.pan.pl/dlibra/journal/136632

A. Kocurek, B. Kowalska, 2018, Inicjowanie konsultacji [w:] M. Nowina Konopka, W. Feleszko, Ł. Małecki (red.), Komunikacja medyczna dla studentów i lekarzy, Kraków, s. 49-55.

Ł. Małecki, 2018, Radzenie sobie z oczekiwaniami pacjenta [w:] M. Nowina Konopka, W. Feleszko, Ł. Małecki (red.), Komunikacja medyczna dla studentów i lekarzy, Kraków, s. 123-140.

M.K. Marvel, R.M. Epstein, K. Flowers, H. Beckman, 1999, Soliciting the patient's agenda: have we improved?, „Journal of the American Medical Association" nr 281(3), s. 283-287.

W.R. Miller, S. Rollnick, 2014, Dialog motywujacy. Jak pomóc ludziom w zmianie, Kraków.

J. Silverman, S. Kurtz, J. Draper, 2018, Umiejętności komunikowania się z pacjentami, Kraków.

A. Stalmach-Przygoda, 2018, Wyjaśnianie i planowanie [w:] M. Nowina Konopka, W. Feleszko, Ł. Małecki (red.), Komunikacja medyczna dla studentów i lekarzy, Kraków, s. 99-114.

S. Trzeciak, A. Mazzarelli, 2019, Compassionomics: The Revolutionary Scientific Evidence that Caring Makes a Difference, Pensacola.

\section{Patient in the centre of conversation on the example of medical students' assignments}

\section{Summary}

This paper presents the main assumptions of patient-centred care, which emphasises the importance of getting to know and taking into account the patient's perspective throughout the treatment process. The aim of this study is to demonstrate how communication skills, which are taught as part of classes in medical communication, facilitate the provision of patient-centred care. The paper discusses selected communication skills and presents fragments of students' assignments demonstrating the practical application of the acquired skills. The studies provide examples of utterances fostering the exchange of perspectives and building of a common look at the patient's problem and reinforcing the patient's sense of being in the centre of care.

Keywords: communication in medicine - patient-centred care - language of medicine - medical education. 